\title{
STRATEGI KEPALA SEKOLAH DALAM MENINGKATKAN KOMPETENSI GURU DI MADRASAH IBTIDAIYAH (MI)
}

\author{
Institut Agama Islam Al-Qodiri Jember \\ Zairotul Malikkhah, Nurul Anam \\ zairotul@gmail.com, nurul.anam86@gmail.com
}

\begin{abstract}
Abstrak: This study is focused on describing the principal's strategy in improving teacher competence at MI Muhammadiyah 03 Wonoasri Tempurejo Jember. The research method used a qualitative approach. The results showed that the principal's strategy in increasing teacher competence in: 1) pedagogical aspects was carried out by providing guidance and supervision to teachers related to the learning process in the classroom; 2) personality aspects are carried out by providing motivation and good examples for teachers to always do the best for students and the progress of the institution; 3) the social aspect is carried out by creating a sense of togetherness and harmony by improving communication between the teacher councils so as to create a harmonious atmosphere in the school environment; and 4) conducted by conducting teacher discipline guidance, involving teachers in training activities, workshops, training, seminars, KKG, MGMP to expand teacher knowledge in order to improve the quality of learning and student achievement. Organizing teacher performance supervision to evaluate teacher performance and improve competence.
\end{abstract}

Keyword: Principal Strategy, Teacher Competence, MI

\section{A. PENDAHULUAN}

Dalam meningkatkan kualitas pendidikan, kepala sekolah harus menempatkan guru sesuai fungsi serta tugasnya. Memberikan sarana dan prasarana untuk mengembangkan potensi yang dimiliki dengan mengikutkan diklat dan workshop sehingga guru bisa menjadi guru yang lebih profesional dalam bidangnya masing-masing. Membuat pengukuran kinerja guru, perbaikan sistem, memberi reword pada guru yang berprestasi. Kepala sekolah menyediakan fasilitas pembelajaran, melakukan pembinaan jabatan guru dan tenaga kependidikan, dan menjalin hubungan yang baik dengan stekholder disekolah.

Kepemimpinan kepala sekolah berperan penting dalam perkembangan sekolah. Jiwa kepemimpinan kepala sekolah dipertaruhkan dalam proses pembinaan para guru, pegawai tata usaha, dan pegawai sekolah lainnya. Sebagai pemimpin, ia harus mengetahui, memahami semua hal yang berkaitan dengan administrasi sekolah dan potensi yang dimiliki oleh para gurunya, sehingga komunikasi dengan 
guru dan karyawan sekolah akan membantu kinerjanya, terutama untuk menyelesaikan masalah yang dihadapi oleh sekolah yang dipimpinnya. ${ }^{1}$

Secara singkat dapat disimpulkan bahwa kepala sekolah memiliki peranan yang strategis dalam rangka meningkatkan kompetensi guru, baik sebagai pendidik, manajer, administrator, supervisor, pemimpin, pencipta iklim kerja maupun sebagai wirausahawan. Seberapa jauh kepala sekolah dapat mengoptimalkan segenap peran yang diembannya, secara langsung maupun tidak langsung dapat memberikan kontribusi terhadap peningkatan profesionalisme guru, dan pada gilirannya dapat membawa efek terhadap peningkatan mutu pendidikan di sekolah. Kompetensi guru merupakan gambaran tentang apa yang seyogyanya dapat dilakukan seseorang guru dalam melaksanakan pekerjaannya, baik berupa kegiatan, berperilaku maupun hasil yang dapat ditunjukkan. Kompetensi guru terdiri dari kompetensi pedagogik, kompetensi kepribadian, kompetensi sosial, dan kompetensi profesional. Sejalan dengan tantangan kehidupan global, peran dan tanggung jawab guru pada masa mendatang akan semakin kompleks, sehingga menuntut guru untuk senantiasa melakukan berbagai peningkatan dan penyesuaian penguasaan kompetensinya.

MI Muhammadiyah 03 Wonoasri Tempurejo Jember merupakan suatu lembaga pendidikan yang mempunyai kualitas yang bagus. Sejarah sekolah ini sebelum tahun 2014, sekolah ini termasuk sekolah yang kurang diminati masyarakat karena sekolah swasta dan bangunan sekolah yang kurang menarik. Animo masyarakat desa, sekolah yang berkualitas adalah sekolah negeri dan mempunyai gedung yang bagus dan megah. ${ }^{2}$ Namun pada tahun ajaran 2014/2015, seiring dengan pergantian kepala sekolah, sekolah ini mulai dilirik masyarakat. Isnaini,S.Pd adalah kepala sekolah yang baru, melalui keuletan serta kegigihannya ia mulai melakukan inovasi dan kerjasama dengan steakholder yang ada untuk mewujudkan sekolah yang berkualitas. ${ }^{3}$

Selain itu, keberhasilan kepala sekolah adalah pada aspek kompetensi guru. Tenaga pengajar yang ada di MI Muhammadiyah 03 Wonoasri Tempurejo Jember merupakan tenaga yang cukup berkualitas, hal ini dapat dilihat bahwa guru yang ada merupakan lulusan sarjana. Selain itu, kualitasnya juga dilihat dari minat orang tua dalam menyekolahkan anaknya di sekolah tersebut dapat dilihat bahwa tiap tahun ajaran baru pendaftar yang ada selalu dalam jumlah yang tinggi. Berdasarkan diskripsi di atas, maka menjadi alasan bagi penulis untuk meneliti bagaimana strategi kepala sekolah di MI Muhammadiyah 03 Wonoasri Tempurejo Jember sehingga sekolah tersebut menjadi salah satu sekolah yang maju dan menjadi sekolah favorit di kecamatan Tempurejo khususnya desa Wonoasri dan sekitarnya.

\footnotetext{
${ }^{1}$ Tatang,S, Supervisi Pendidikan, (Bandung: Pustaka Setia, 2016), h.87

${ }^{2}$ Isnaini, Wawancara, Wonoasri, 09 April 2019.

${ }^{3}$ Observasi Lapangan tanggal 09 April 2019
} 


\section{B. KAJIAN PUSTAKA}

\section{Kepala Sekolah}

Secara etimologi kepala sekolah adalah guru yang memimpin sekolah. ${ }^{4}$ Kata kepala sekolah terdiri dari dua kata kunci yaitu kepala dan sekolah. Kepala berarti ketua atau pemimpin dalam sebuah organisasi atau lembaga. Sedangkan sekolah adalah sebuah lembaga tempat menerima dan memberi pelajaran. Sedangkan secara terminologi, kepala sekolah dapat diartikan sebagai tenaga fungsional guru yang diberi tugas untuk memimpin suatu sekolah tempat diselenggarakan proses belajar mengajar, atau tempat terjadinya interaksi antara guru yang memberi pelajaran dan murid yang menerima pelajaran. ${ }^{5}$

Keberhasilan suatu lembaga pendidikan sangat tergantung pada kepemimpinan kepala sekolah. Karena kepala sekolah sebagai pemimpin dilembaganya, maka dia harus mampu membawa lembaganya kearah tercapainya tujuan yang telah ditetapkan, ia harus mampu melihat adanya perubahan serta mampu melihat masa depan dalam kehidupan globalisasi yang lebih baik. Kepala sekolah harus bertanggung jawab atas kelancaran dan keberhasilan semua urusan pengaturan dan pengelolaan secara formal kepada atasannya atau informal kepada masyarakat yang telah menitipkan anak didiknya.

\section{Kompetensi Guru}

Guru adalah pendidik, yang menjadi tokoh, panutan, dan identifikasi bagi para peserta didik, dan lingkungannya. Oleh karena itu, guru harus memiliki standar kualitas pribadi tertentu, yang mencakup tanggung jawab, wibawa, mandiri, dan disiplin. ${ }^{6}$ Dalam UU Nomor 14 Tahun 2005 tentang guru dan dosen, pasal 1 ayat (1) dinyatakan bahwa: Guru adalah pendidik profesional dengan tugas utama mendidik, mengajar, membimbing, mengarahkan, melatih, menilai, dan mengevaluasi peserta didik pada pendidikan anak usia dini jalur pendidikan formal, pendidikan dasar, dan pendidikan menengah. ${ }^{7}$

Kompetensi yang dimiliki oleh guru diartikan pemilikan, penguasaan, ketrampilan dan kemampuan yang dituntut jabatan seseorang, maka seorang guru harus menguasai kompetensi guru, sehingga dapat melaksanakan kewenangan profesionalnya. Nurul Anam dan Moh, Rofid Fikroni (2020: 76) menjelaskan bahwa kompetensi guru jika dikontekstualisasikan pada Nabi Muhammad sebagai pendidik, maka ada beberapa kompetensi atau sifat wajib yang dimuliki Nabi Muhammah yaitu kompetensi shidiq (jujur), amanah (dipercaya), tabligh (menyampaikan) dan fathanah (cerdas). Empat kompetensi atau sifat tersebut memiliki relevansi orientasi yang sama dengan empat kompetensi seorang

\footnotetext{
${ }^{4}$ W.J.S. Poerwadarminto, Kamus Umum Bahasa Indonesia, (Jakarta: Balai Pustaka, 1985), h.428

${ }^{5}$ Wahyosumidjo, Kepemimpinan kepala sekolah; Tinjauan Teoritikdan Permasalahannya, (Jakarta:

Raja Grafindo Persada, 2007), h.88

${ }^{6}$ E. Mulyasa, Menjadi Guru ProfesionalMenciptakan Pembelajaran Kreatif dan Menyenangkan (Bandung: PT. Remaja Rosdakarya, 2017), h.37

${ }^{7}$ Tukiran Taniredja,dkk, Guru yang Profesional (Bandung: Alfabeta, 2018), h.130
} 
pendidik sebagaimana yang diamanatkan dalam UU No. 14 Tahun 2005 tentang guru dan dosen, yaitu kompetensi paedagogik, kepribadian, sosial dan professional. Adapun pemjelasan empat kompetensi yang harus dimiliki seorang guru, yaitu: 1) Kompetensi Pedagogik. Kompetensi pedagogik adalah kemampuan mengelola pembelajaran peserta didik yang meliputi pemahaman terhadap peserta didik, perancangan dan pelaksanaan pembelajaran peserta didik, evaluasi hasil belajar, dan pengembangan peserta didik untuk mengaktualisasikan sebagai potensi yang dimilikinya; ${ }^{8}$ 2) Kompetensi Kepribadian. Kompetensi kepribadian adalah kemampuan kepribadian yang mantap, berakhlak mulia, arif dan wibawa, serta menjadi teladan peserta didik; 3) Kompetensi Sosial. Kompetensi sosial adalah kemampuan guru untuk berkomunikasi dan berinteraksi secara efektif dan efisien dengan peserta didik, sesama guru, orangtua/wali peserta didik, dan masyarakat sekitar $;^{10}$ dan 4) Kompetensi Profesional. Kompetensi profesional adalah kemampuan penguasaan materi pelajaran secara luas dan mendalam. ${ }^{11}$

\section{Strategi kepala sekolah dalam meningkatkan kompetensi guru.}

Kepala sekolah memiliki berbagai potensi yang dapat dikembangkan secara optimal. Setiap kepala sekolah harus memiliki perhatian yang cukup tinggi terhadap peningkatan kualitas pendidikan di sekolah. Perhatian tersebut harus ditunjukkan dalam kemauan dan kemampuan untuk mengembangkan diri dan sekolahnya secara optimal. ${ }^{12}$ Dalam meningkatkan kompetensi guru, kepala sekolah dituntut untuk memiliki strategi khusus yang bisa memudahkan kepala sekolah tersebut dalam melaksanakan tugasnya. Oleh karena itu, dalam usaha untuk meningkatkan kompetensi guru, strategi yang harus digunakan oleh kepala sekolah yaitu:

Pertama, Pembinaan Disiplin Guru. Hal ini dimaksudkan agar guru mampu merespon perubahan dan tuntutan perkembangan IPTEK dan kemajuan kemasyarakatan, termasuk perubahan sistem pendidikan. Pendidikan dan Pelatihan Tenaga Guru (PPTG) terdiri dari dua jenis, yaitu: a) Pendidikan prajabatan (preservice education), adalah pendidikan persiapan mahasiswa untuk meniti karir dalam bidang pendidikan dan pengajaran; dan b) Pendidikan dalam jabatan (interservice education), Pendidikan dalam jabatan merupakan salah satu aktivitas untuk meningkatkan dan mengembangkan kemampuan guru, baik secara pribadi, sosial, maupun profesionalnya. Praksisnya merupakan aktivitas pendidikan, pelatihan dan pengembangan yang dimaksudkan untuk

\footnotetext{
${ }^{8}$ Tatang, S, Supervisi Pendidikan (Bandung: Pustaka Setia, 2016), h.203

${ }^{9}$ Ibid

${ }^{10}$ Ibid

${ }^{11}$ Ibid

${ }^{12}$ E. Mulyasa, Menjadi Kepala Sekolah Profesional (Bandung: PT Remaja Rosdakarya, 2018), h. 70
} 
meningkatkan kemampuan dan ketrampilan staf, sejalan dengan perkembangan ilmu pengetahuan, teknologi dan tuntutan masyarakat. ${ }^{13}$

Kedua, Pemberian Motivasi. Sebagai pemimpin yang bertanggung jawab terhadap pencapaian tujuan dengan melalui orang lain atau karyawan, mereka diharapkan mempunyai kemampuan untuk memotivasi para karyawan.dengan memahami apa yang menjadi kebutuhan mereka dan berusaha untuk menyiapkan alat-alat pemenuhan kebutuhan para karyawan maka seorang pemimpin akan dapat mendorong para karyawannya untuk bekerja lebih giat. ${ }^{14}$ Dalam hal ini motivasi diberikan kepada para guru agar terus meningkatkan profesionalitasnya sebagai pendidik, sehingga nantinya dapat menghasilkan pembelajaran yang berkualitas dan menghasilkan lulusan yang berprestasi. Ketiga, Penataran dan lokakarya. Pelaksanakan penataran dan lokakarya untuk meningkatkan kemampuan guru dalam melaksanakan proses belajar mengajar dapat dilakukan oleh sekelompok guru yang mempunyai maksud sama. Pelaksanaannya dilakukan dengan cara mengundang seorang atau beberapa orang pakar sebagai narasumber. Dengan demikian, para guru tidak hanya memperoleh bekal-bekal pengetahuan, tetapi juga dapat meningkatkan kemampuan dan keterampilan mengajarnya. Untuk mengetahui penambahan atau peningkatan pengetahuan pada akhir kegiatan dilakukan evaluasi atas kemampuan dan keterampilan hasil pelaksanaan lokakarya.

Keempat, Supervisi. Menurut Ngalim Purwanto dalam bukunya Tatang, S mengatakan, Supervisi adalah bantuan dari pemimpin sekolah untuk perkembangan kepemimpinan para guru dan personel sekolah dalam mencapai tujuan pendidikan yang berupa dorongan, bimbingan, kesempatan bagi pertumbuhan keahlian dan kecakapan para guru, seperti bimbingan dalam usaha dan pelaksanaan dalam pendidikan dan pengajaran, pemilihan alat-alat pelajaran dan metode mengajar yang lebih baik, cara penilaian yang sistematis terhadap fase seluruh proses pengajaran. Jelasnya, supervisi adalah aktivitas pembinaan yang direncanakan untuk membantu guru dan pegawai sekolah lainnya dalam melakukan pekerjaan mereka secara efektif. ${ }^{15}$ Pelaksanaan supervisi dilakukan oleh kepala sekolah setahun empat kali. Dua kali di semester ganjil dan dua kali pada semester genap. Tujuan dilaksanakannya supervisi sama-sama ingin meningkatkan kemampuannya dalam melaksanakan proses belajar mengajar.

Kelima, menumbuhkan kreativitas guru. Para guru dipandang sebagai orang yang paling mengetahui kondisi belajar, juga permasalahan belajar yang dihadapi oleh para peserta didiknya. Karena hampir setiap hari mereka berhadapan dengan peserta didik mereka. Guru kreatif selalu mencari cara bagaimana agar proses belajar mencapai hasil sesuai dengan tujuan, serta berupaya menyesuaikan pola-pola tingkah lakunya

\footnotetext{
${ }^{13}$ E. Mulyasa, Menjadi Kepala Sekolah Profesional (Bandung: PT Remaja Rosdakarya, 2018), h. 46

${ }^{14}$ Bambang Swasto, Manajemen Sumber Daya Manusia (Malang: Fakultas Ilmu Administrasi Universitas Brawijaya, 1996), h. 71

${ }^{15}$ Tatang, S, Supervisi Pendidikan (Bandung: CV Pustaka Setia, 2016), h. 57
} 
dalam mengajar dengan tuntutan pencapaian tujuan, dengan mengembangkan faktor situasi kondisi belajar peserta didik. Kreatifitas yang demikian, memungkinkan guru yang bersangkutan menemukan bentuk-bentuk mengajar yang sesuai, terutama dalam memberi bimbingan, rangsangan, dorongan, dan arahan agar peserta didik dapat belajar secara efektif. Keenam, mengembangkan tenaga pendidik. Tenaga atau sumber daya yang telah diperoleh suatu organisasi, perlu pengembangan sampai pada taraf tertentu sesuai dengan pengembangan organisasi itu. Pengembangan sumber daya ini penting searah dengan pengembangan organisasi. ${ }^{16}$

\section{METODE PENELITIAN}

Pendekatan penelitian ini menggunakan pendekatan kualitatif deskriptif. Pendekatan ini merupakan suatu proses pengumpulan data secara sistematis dan intensif untuk memperoleh pengetahuan tentang strategi kepala sekolah dalam meningkatkan kompetensi guru di $\mathrm{Ml}$ Muhammadiyah 03 Wonoasri Tempurejo Jember.

Peneliti mengambil objek penelitian di MI Muhammadiyah 03 Wonoasri, Tepatnya berada di Jl. Mojopahit gang 7 Wonoasri kecamatan Tempurejo Kabupaten Jember. Letak sekolah tersebut sangat strategis yakni berada di tepi jalan dan mudah dijangkau oleh kendaraan umum. Peneliti tertarik dengan MI Muhammadiyah 03 Wonoasri, karena sekolah ini termasuk sekolah yang muridnya terbanyak di kecamatan Tempurejo tepatnya berada di desa Wonoasri. MI Muhammadiyah 03 Wonoasri merupakan sekolah yang banyak diminati dan digemari oleh pelajar lulusan PAUD, TK dan RA yang berada di desa Wonoasri dan sekitarnya. ${ }^{17}$

Dalam penelitian ini teknik penentuan informan yang digunakan dengan cara purposive sampling dan snowball sampling. Purposive sampling adalah teknik pengambilan sampel (informasi) dengan pertimbangan tertentu. Sedangkan snowball sampling adalah tehnik pengambilan sampel yang pada awalnya jumlahnya sedikit lama-lama menjadi besar. ${ }^{18}$ Beberapa sumber data yang dimanfaatkan dalam penelitian ini meliputi: 1) sumber data utama (primer) yaitu sumber data yang diambil peneliti melalui wawancara dan observasi. Sumber data tersebut meliputi: Kepala sekolah MI Muhammadiyah 03 Wonoasri, Waka kurikulum, Guru/Operator, dan Guru Kelas; dan 2) Sumber data tambahan (sekunder), yaitu sumber data di luar kata-kata dan tindakan yakni sumber data tertulis antara lain: Sejarah Berdirinya MI Muhammadiyah 03 Wonoasri, Visi Misi dan Tujuan Ml Muhammadiyah 03 Wonoasri dan sebagainya.

Teknik-teknik yang digunakan peneliti dalam mengumpulkan data tersebut adalah sebagai berikut: pertama, Observasi. Adapun observasi yang di lakukan peneliti termasuk dalam jenis observasi partisipatif dan

\footnotetext{
${ }^{16}$ Soekidjo Notoatmodjo, Pengembangan Sumber Daya Manusia (Jakarta: Rineka Cipta, 1998), h. 115

${ }^{17}$ Observasi di MIM 03 Wonoasri, 06 April 2019

${ }^{18}$ Sugiono, Metode Penelitian Kuantitatif, Kualitatif dan R \& D (Bandung: Alfabeta, 2008), h.218
} 
observasi terus terang atau tersamar. Yaitu peneliti terlibat langsung dengan kegiatan sehari-hari orang yang sedang di amati atau yang di gunakan sebagai sumber data penelitian. Disamping itu peneliti menyatakan keterusterangannya kepada nara sumber bahwa ia sedang melakukan penelitian. Sambil melakukan pengamatan, peneliti ikut melakukan apa yang di kerjakan oleh sumber data. Teknik ini dipergunakan untuk memperoleh gambaran umum mengenai kondisi objektif MI Muhammadiyah 03 Wonoasri Tempurejo Jember baik di bidang sarana, fisik, keadaan siswa, tenaga pendidik dan kegiatan belajar dan pelaksanaan strategi Kepala Sekolah dalam meningkatkan kompetensi guru di MI Muhammadiyah 03 Wonoasri Tempurejo Jember.

Kedua, Interview (Wawancara). Jenis wawancara yang di gunakan peneliti adalah wawancara semi terstruktur karena pewawancara tidak mengajukan persoalan berdasarkan daftar pertanyaan yang telah disiapkan. Adapun data yang ingin di peroleh dari wawancara yang peneliti lakukan adalah strategi Kepala Sekolah dalam meningkatkan kompetensi guru pada aspek pedagogik, social, kepribadian dan profesional di Ml Muhammadiyah 03 Wonoasri Tempurejo Jember. Ketiga, Dokumentasi. Dokumentasi yang peneliti gunakan adalah dengan mengumpulkan data yang ada di kantor MI Muhammadiyah 03 Wonoasri, tepatnya diperoleh dari bagian operator dan kurikulum, baik berupa tulisan (data siswa, guru, fasilitas), gambar (struktur organisasi), dan dokumen terkait lainnya yaitu dokumentasi untuk memperoleh data tentang strategi kepala sekolah dalam meningkatkan kompetensi guru di $\mathrm{MI}$ Muhammadiyah 03 Wonoasri Tempurejo Jember.

Setelah berbagai data terkumpul, maka untuk menganalisisnya digunakan teknik analisis deskriptif, artinya peneliti berupaya menggambarkan kembali data-data yang terkumpul mengenai strategi kepala sekolah dalam meningkatkan kompetensi guru di MI Muhammadiyah 03 Wonoasri. Proses analisis data dalam penelitian ini mengandung tiga komponen utama, yaitu: Reduksi Data, Penyajian Data (Display Data), dan Verifikasi (Menarik Kesimpulan).

Dalam penelitian ini penulis menggunakan triangulasi yang berdasarkan dengan sumber yang artinya membandingkan dan mengecek balik derajat kepercayaan suatu informasi yang diperoleh melalui waktu dan alat yang berbeda dalam penelitian kualitatif. Dan hal ini dapat dicapai dengan jalan: (1) membandingkan data hasil pengamatan dengan data hasil wawancara, (2) membandingkan apa yang dikaitkan orang didepan umum dengan apa yang dikatakannya secara pribadi, (3) membandingkan apa yang dikatakan orang-orang tentang situasi penelitian dengan apa yang dikatakan sepanjang waktu, (4) membandingkan keadaan dan prespektif seseorang dengan berbagai pendapat dan pandangan orang seperti rakyat biasa, orang yang berpendidikan menengah atau perguruan tinggi, orang berada, orang pemerintah, (5) membandingkan hasil wawancara dengan isi suatu dokumen yang berkaitan. ${ }^{19}$

\footnotetext{
${ }^{19}$ Lexy J Moleong, Metodologi Penelitian Kualitatif (Bandung: PT. Remaja Rosdakarya, 2016), h. 330
} 


\section{HASIL DAN PEMBAHASAN PENELITIAN}

\section{Strategi Kepala Sekolah Dalam Meningkatkan Kompetensi Guru Pada Aspek Pedagogik di MI Muhammadiyah 03 Wonoasri}

Salah satu kompetensi yang harus dimiliki oleh seorang guru adalah kompetensi pedagogik. Untuk mengetahui lebih jelas tentang kompetensi pedagogik peneliti mengadakan wawancara dengan kepala sekolah $\mathrm{MI}$ Muhammadiyah 03 Wonoasri. Berikut wawancara peneliti dengan lbu Isnaini,S.Pd selaku kepala sekolah terkait dengan kompetensi pedagogik guru :

Guru bisa dikatakan sudah memiliki kompetensi pedagogik apabila guru tersebut mampu melaksanakan tugasnya sebagai pendidik yaitu mampu memahami karakter peserta didik, dapat menjelaskan materi pelajaran dengan baik, mampu memberikan evaluasi terhadap apa yang sudah diajarkan, dan juga guru mampu mengembangkan potensi yang dimiliki oleh peserta didik serta guru yang memiliki sumber daya manusia yang sesuai dengan tupoksinya. $^{20}$

Dari hasil observasi yang dilakukan oleh peneliti kompetensi pedagogik guru di MI Muhammadiyah 03 Wonoasri ini bisa dibilang bagus. Hal tersebut bisa dilihat pada saat guru menyampaikan materi dengan menarik sehingga para peserta didik antusias untuk memperhatikan guru dan guru menyampaikan materi sesuai dengan RPP yang telah dibuat. ${ }^{21}$

Dari penjelasan Ibu Isnaini, bahwa kompetensi pedagogik guru juga dilihat pada kemampuan guru dalam membuat dan menyusun perangkat pembelajaran. Fungsi perangkat pembelajaran adalah untuk mempermudah guru dalam menyampaikan materi pelajaran. Selain itu di dalam Rencana Pelaksanaan Pembelajaran (RPP) sudah tersusun urutan materi yang akan disampaikan juga ada kriteria penilaian dari materi yang diajarkan. Sehingga hal ini dapat membantu guru dalam melakukan penilaian terhadap peserta didik.

Bapak Tusbani, S.Pd selaku wakil kepala bidang kurikulum Menjelaskan terkait kompetensi pedagogik guru dalam penyusunan perangkat pembelajaran:

Kaitan guru-guru di MIM 03 Wonoasri ini memang untuk perangkat pembelajaran itu memang diwajibkan untuk membuat terutama bagi mereka yang sudah memegang wali kelas dan guru mata pelajaran. Perangkat itu meliputi prota kemudian promes silabus dan RPP, yang itu merupakan syarat utama yang ditekankan oleh ibu kepala sekolah selaku manajerial di MIM 03 Wonoasri. Selain itu juga sebagai dasar untuk penilaian bagi kinerja guru. Dan terutama bagi guru-guru yang sudah sertifikasi itu merupakan penekanan dan wajib untuk membuat semua mata pelajaran kaitan dengan acuan untuk pencairan TPP yang ada di MIM 03 Wonoasri khususnya di Kemenag. ${ }^{22}$

\footnotetext{
${ }^{20}$ Isnaini, S.Pd, Wawancara, Wonoasri, 08 Juli 2019.

${ }^{21}$ Observasi Lapangan tanggal 16 Juli 2019.

${ }^{22}$ Tusbani,S.Pd, Wawancara, Wonoasri, 12 Juli 2019.
} 
Ibu Rida Ria Susanti, selaku guru kelas di MI Muhammadiyah 03 juga menjelaskan terkait mengikuti diklat ataupun pelatihan:

lya benar bu. Ibu Isnaini selaku kepala sekolah sering mengikutkan guru-guru yang ada di MIM 03 Wonoasri ini untuk mengikuti Diklat, pelatihan dll. Saya selaku guru kelas selama periode beliau sudah mengikuti diklat kurikulum 2013 sebanyak 3 (tiga) kali. Yang pertama di MTsN Jember tahun 2014, kemudian di MIHM Sidodadi tahun 2015 dan yang terakhir di MI Sunan Giri tahun 2018. Itu untuk semua guru lo bu bukan saya saja. Guru yang diikutkan secara bergantian supaya semua menjadi pintar dan bisa mengajar dengan baik. ${ }^{23}$

Berdasarkan hasil wawancara, observasi di lapangan dan beberapa dokumentasi yang peneliti kumpulkan, dapat peneliti simpulkan bahwa strategi kepala sekolah dalam meningkatkan kompetensi pedagogik guru di Ml Muhammadiyah Wonoasri telah dilaksanakan dengan baik dan semua dewan guru melaksanakannya dengan senang tanpa ada paksaan ataupun tertekan. Guru-guru di MI Muhammadiyah 03 Wonoasri sebagian besar telah melaksanakan sesuai TUPOKSI masing-masing guru.

\section{Strategi Kepala Sekolah Dalam Meningkatkan Kompetensi Guru Pada Aspek Kepribadian di MI Muhammadiyah 03 Wonoasri}

Menjadi seorang guru bukanlah hal yang mudah dan bukan pula sesuatu yang tidak bisa dilakukan dengan baik. Guru harus bisa mempengaruhi peserta didik ke arah yang lebih baik sesuai dengan tata nilai yang dianggap baik dan berlaku dalam masyarakat. Ibu Isnaini selaku kepala sekolah menjelaskan terkait kompetensi kepribadian guru:

Kompetensi kepribadian guru adalah guru yang mampu menjadi teladan yang baik. Guru yang mampu dijadikan suri tauladan bagi setiap peserta didik. Guru yang mampu memberi kenyamanan bagi peserta didik. Dan juga guru yang mampu menjunjung tinggi kode etik guru. Seorang guru harus bisa menanamkan nilai-nilai baik pada peserta didik, salah satunya guru harus bisa memberi contoh kedisiplinan. Disiplin dalam penggunaan kata, disiplin dalam penggunaan waktu, dan disiplin dalam setiap perbuatan. ${ }^{24}$ Untuk meningkatkan kompetensi kepribadian guru yang saya lakukan adalah saya mulai dari diri saya sendiri. Saya sebagai kepala sekolah harus mampu menjadi contoh yang baik bagi semua guru yang ada di MIM 03 Wonoasri. Terutama belajar untuk selalu disiplin. Karena pengaruh dari seorang kepala sekolah akan berdampak besar bagi guru-guru yang lain. Kalau kita mempunyai prilaku yang baik, tidak hanya bisa memberi perintah tapi memberi teladan yang baik, maka kita sebagai kepala sekolah akan disegani dan ditiru oleh guru juga anak-anak. ${ }^{25}$

\footnotetext{
${ }^{23}$ Rida Ria Susanti, SH, Wawancara, Wonoasri, 12 Juli 2019.

${ }^{24}$ Isnaini, S.Pd, Wawancara, Wonoasri, 09 Juli 2019.

${ }^{25}$ Isnaini,S.Pd, Wawancara, Wonoasri, 09 Juli 2019.
} 
Berdasarkan hasil observasi dilapangan terkait pembinaan disiplin guru, kepala sekolah sangat tegas dalam menangani guru yang sering terlambat ataupun tidak masuk ke sekolah. Salah satu contoh saat beliau pertama kali diangkat menjadi kepala sekolah, ada satu guru PNS yang tidak pernah masuk ke sekolah. Kemudian beliau konsultasi dengan pengawas Madrasah Ibtidaiyah kecamatan Tempurejo dan melalui rapat dewan guru dan yayasan akhirnya guru PNS tersebut dikembalikan kepada Kepala Kantor Kementerian Agama Kabupaten Jember. Hal ini dilakukan agar dewan guru tidak mengikuti apa yang dilakukan guru PNS tersebut, dan semua bisa menjalankan tugasnya sebagai guru sesuai dengan TUPOKSInya. ${ }^{26}$

Berikut pemaparan Bapak Fery Adi Irawan yang menjabat sebagai operator sekaligus guru di MI Muhammadiyah 03 Wonoasri:

lya benar, kepala sekolah kami memang mengadakan pembinaan disiplin guru. Beliau selalu datang tepat waktu bahkan terkadang lebih pagi dari guru-guru yang lain. Di sini setiap pagi sejak jam 06.10 WIB ada guru piket yang berada di gerbang sekolah menyambut para peserta didik yang datang ke sekolah. Semua guru pulang dari sekolah setelah mengadakan sholat Dhuhur berjama'ah di Masjid Al Istiqomah. Hal seperti ini kami lakukan secara bersamasama. Awalnya memang terasa berat namun ketika kita lakukan dengan ikhlas dan di niati untuk ibadah maka akan terasa biasabiasa saja tanpa ada beban. Alhamdulillah, kegiatan disiplin guru ketika diterapkan bersama-sama dampaknya sangat bagus. Peserta didik yang mendaftar di MIM semakin banyak, orang tua mempercayakan dan mendukung secara penuh dalam segi finansial, dan tentunya semua elemen masyarakat percaya pada lembaga kami. $^{27}$

Berikut pemaparan Ibu Rida Ria Susanti,S.Pd selaku guru kelas 1 mengenai tanggung jawab seorang guru:

Saya sebagai guru di MIM 03 Wonoasri mempunyai tanggung jawab penuh atas pekerjaan saya. Misalnya setiap hari saya harus masuk sekolah, supaya kelas yang menjadi tanggung jawab saya tidak kosong dalam penyampaian materi pelajaran. Jika saya tidak bisa masuk karena sakit atau ada hal lain, maka saya harus menghubungi guru piket untuk menggantikan saya. Saya juga harus memberikan RPP yang sudah saya buat sekaligus materi pelajaran, agar anak-anak tidak ketinggalan pelajaran dan materi pelajaran dapat disampaikan sesuai target kurikulum. Terutama saya sebagai guru kelas 1, saya usahakan sebisa mungkin untuk selalu masuk sekolah. Kalau bukan karena urusan yang sangat mendesak saya akan tetap masuk. ${ }^{28}$

\footnotetext{
${ }^{26}$ Observasi Lapangan tanggal 25 Juli 2019.

${ }^{27}$ Fery Adi Irawan, Wawancara, Wonoasri, 12 Juli 2019.

${ }^{28}$ Rida Ria Susanti,SH, Wawancara, Wonoasri, 12 Juli 2019.
} 
Berdasarkan hasil wawancara, observasi di lapangan, dan dokumen tata usaha MI Muhammadiyah 03 Wonoasri, peneliti menyimpulkan bahwasanya dalam meningkatkan kompetensi kepribadian guru oleh kepala sekolah telah berjalan dengan baik. Hal ini dapat dilihat pada kedisiplinan guru saat melaksanakan tugas sebagai guru dan beberapa kegiatan yang mencerminkan sikap pembiasaan yang baik bagi peserta didik.

\section{Strategi Kepala Sekolah Dalam Meningkatkan Kompetensi Guru Pada Aspek Sosial di MI Muhammadiyah 03 Wonoasri}

Dalam meningkatkan kompetensi sosial guru, lbu Isnaini Selaku Kepala Sekolah memaparkan sebagai berikut:

Untuk meningkatkan kompetensi sosial guru, sebagai kepala sekolah saya harus bisa menjalin komunikasi yang baik, akrab, dan terbuka dengan semua guru. Sehingga antara kepala sekolah dan guru serta staf yang ada tidak ada kesenjangan. Begitu juga antar sesama guru dan staf yang ada di lembaga. ${ }^{2}$

Ibu Rida Ria Susanti selaku guru kelas 1 menambahkan terkait dengan komunikasi yang baik antar sesama guru:

Untuk menjaga komunikasi agar tetap terjaga dengan baik, setiap bertemu kami saling menyapa dan berjabat tangan serta berkomukasi yang baik. Kami menerapkan $3 \mathrm{~S}$ yaitu Senyum Sapa Salam. Dan khusus ibu guru kami membiasakan untuk cium pipi kanan dan kiri. Hal ini dilakukan supaya kami terasa akrab dan saudara dekat. Kemudian saling menjaga ucapan yang sekiranya dapat menyakiti atau menyinggung teman guru maka kita hindari. Kita saling berusaha memahami satu sama lain menjaga perasaan. Dan alhamdulillah, diantara kami jarang sekali ada pertikaian yang dapat menimbulkan ketidak harmonisan diantara kami. ${ }^{30}$

Dari hasil observasi di lapangan yang peneliti lakukan terkait kompetensi sosial guru, memang guru-guru di MI Muhammadiyah 03 Wonoasri ini saat bertemu selalu menerapkan $3 \mathrm{~S}$ yaitu Senyum Sapa dan salam. Peneliti melihat hubungan tersebut begitu akrab, bahkan jika ibu guru saling bertemu selalu diakhiri dengan cium pipi kiri dan kanan. Sehingga hal tersebut menumbuhkan rasa senang pada peserta didik dan para bapak ibu guru menjadi idola bagi peserta didik. ${ }^{31}$

Berikut ini pemaparan Ibu Isnaini terkait strategi kepala sekolah dalam meningkatkan kompetensi sosial guru:

Dalam meningkatkan kompetensi sosial guru, saya selalu memotivasi guru-guru untuk selalu berbuat baik pada semuanya. Baik dengan peserta didik, sesama guru maupun dengan masyarakat. Karena saya yakin jika kita menanam kebaikan maka kita akan memanen buah kebaikan tersebut. Kita berbuat baik pada

\footnotetext{
${ }^{29}$ Isnaini,S.Pd, Wawancara, Wonoasri, 10 Juli 2019.

${ }^{30}$ Rida Ria Susanti,S.H, Wawancara, Wonoasri, 12 Juli 2019.

${ }^{31}$ Observasi Lapangan tanggal 24 Juli 2019.
} 
peserta didik, peserta didik merasa senang dan nyaman pada kita tentunya hal tersebut akan menimbulkan rasa kepuasan tersendiri bagi orang tuanya. Orang tua merasa senang anaknya betul-betul diopeni dan dibimbing dengan baik. Saya juga memotivasi mereka untuk menjalin hubungan yang baik dengan sesama guru, saling membantu, dan berusaha untuk melakukan yang terbaik. ${ }^{32}$

Berdasarkan hasil wawancara, observasi dan dokumentasi berupa video rekaman saat guru menyambut peserta didik di gerbang sekolah, strategi kepala sekolah dalam meningkatkan kompetensi sosial guru di MIM 03 Wonoasri ini sangat baik dan perlu dipertahankan.

\section{Strategi Kepala Sekolah Dalam Meningkatkan Kompetensi Guru Pada Aspek Profesional di MI Muhammadiyah 03 Wonoasri}

Kompetensi profesional guru yaitu pada pengetahuan guru dalam memahami materi. Berikut pemaparan lbu Isnaini terkait dengan strategi dalam meningkatkan kompetensi profesional guru:

Setiap guru diberi kesempatan untuk mengikuti KKG, MGMP, lokakarya, pelatihan, seminar, diklat maupun workshop yang diadakan KKMI (Kelompok Kerja Madrasah Ibtidaiyah), Kementerian Agama maupun dari instansi lain baik dalam lingkup Jember maupun luar kabupaten. Untuk KKMI, biasanya kami mengirimkan delegasi sesuai kuota yang telah ditentukan. Bagi guru yang mengikuti kegiatan tersebut akan menyampaikan materi dan mengajarkan kepada guru yang lain agar semua tahu dan bisa mengembangkan ilmunya. Kemudian kami juga mengadakan pembinaan semua dewan guru yang bertujuan untuk menumbuhkan kreatifitas guru, memotivasi guru serta mengembangkan kemampuan guru. ${ }^{33}$

Dalam supervisi yang dibahas biasanya mengenai penilaian kinerja guru dalam mengajar dan menjalankan tugasnya. Kemudian supervisi ini dilakukan dalam satu semester dua kali baik di dalam kelas maupun di luar kelas selama guru tersebut sedang melaksanakan proses pembelajaran pada peserta didik. Dengan adanya supervisi ini guru selalu siap membuat perangkat pembelajaran dan melaksanakan tugas dan fungsinya sebagai seorang pendidik. ${ }^{34}$

Dari hasil observasi di Ml Muhammadiyah 03 Wonoasri peneliti melihat pada perangkat pembelajaran guru-guru di MI Muhammadiyah 03 Wonoasri sangat lengkap. Buku guru tersebut terdiri dari buku kerja 1, 2 dan 3. Buku kerja 1 berisi hasil KKM, RPP, Silabus, SKL, KI dan KD. Untuk buku kerja 2 berisi alokasi waktu, ikrar guru, jurnal agenda guru, kalender pendidikan, kode etik guru, pembiasaan guru, prosem, prota, dan tata tertib guru. Adapun untuk buku kerja 3 berisi analisis butir soal, analisis hasil ulangan, daftar buku pegangan guru dan siswa, daftar hadir

\footnotetext{
${ }^{32}$ Isnaini, S.Pd, Wawancara, Wonoasri, 10 Juli 2019.

${ }^{33}$ Isnaini,S.Pd, Wawancara, Wonoasri, 11 Juli 2019.

${ }^{34}$ Isnaini,S.Pd, Wawancara, Wonoasri, 11 Juli 2019.
} 
siswa, daftar nilai siswa, jadwal mengajar, kumpulan kisi soal, kumpulan soal, penilaian akhlak kepribadian, perbaikan soal, program perbaikan dan pengayaan. Dan untuk buku kerja 4 berisi daftar evaluasi diri kerja guru dan program tindak lanjut kerja guru. ${ }^{35}$

Hal ini juga dibenarkan oleh Bapak Tusbani terkait supervisi guru;

lya benar, kepala sekolah selalu mengadakaan supervisi pada semua dewan guru. Dalam satu semester kami di supervisi sebanyak dua kali. Awal bulan pembelajaran dan akhir bulan setelah pembelajaran selesai. Manfaat diadakannya supervisi tersebut dapat kami rasakan sangat banyak sekali. Kami tidak lagi kesulitan cara pembuatan dan penyusunan perangkat pembelajaran. Hasil supervisi juga mempermudah kami dalam melengkapi berkas sertifikasi kami. Di samping itu, hasil kegiatan supervisi mempermudah lembaga saat dilaksanakan akreditasi karena seluruh file sudah lengkap tinggal melengkapi sebagian kecil saja. ${ }^{36}$

Hal tersebut juga dibenarkan oleh Ibu Rida Ria Susanti selaku guru kelas, beliau menyampaikan:

lya benar bu. Kami sebagai guru di MIM 03 Wonoasri ini setiap tahun selalu di supervisi oleh kepala sekolah. Beliau melakukan supervisi pada semua guru. Jika ada yang kurang maksimal maka beliau selaku kepala sekolah mengadakan program tindak lanjut hasil supervisi dengan mengadakan bimbingan mandiri maupun diikutkan pada diklat ataupun pelatihan yang diadakan oleh Kementerian Agama Kabupaten Jember. ${ }^{37}$

Dengan demikian strategi kepala sekolah dalam meningkatkan kompetensi profesional guru di MI Muhammadiyah 03 Wonoasri sudah berjalan sesuai dengan fungsinya. Mulai dari pengawasan, pembinaan, dan lain-lain. Sehingga usaha yang dilakukan kepala sekolah terhadap peningkatan kompetensi profesional guru ini sangat positif terhadap semua guru dan layak untuk tetap dipertahankan.

Kepala Sekolah adalah pemimpin di sekolah termasuk juga kepala sekolah di MI Muhammadiyah 03 Wonosari. Menurut Sudarwan Danim dalam buku Jamal Ma'mur Asmani, kepala sekolah adalah guru yang mendapatkan tugas tambahan sebagai kepala sekolah. ${ }^{38}$ Daryanto juga menjelaskan bahwa kepala sekolah adalah pemimpin pada suatu lembaga satuan pendidikan. Kepala sekolah ialah pemimpin lembaga satuan pendidikan. Kepala sekolah ialah pemimpin yang proses kehadirannya dapat dipilih secara langsung, ditetapkan oleh yayasan, atau ditetapkan oleh pemerintah. ${ }^{39}$

\footnotetext{
${ }^{35}$ Observasi Lapangan tanggal 26 Juli 2019.

${ }^{36}$ Tusbani,S.Pd, Wawancara, Wonoasri, 11 Juli 2019.

${ }^{37}$ Rida Ria Susanti, S.H, Wawancara, Wonoasri, 12 Juli 2019.

${ }^{38}$ Jamal Ma'mur Asmani, Tips Menjadi Kepala Sekolah Profesional (Jogjakarta: Diva Press, cet. ke-1, 2012), h. 16.

${ }^{39}$ Jamal Ma'mur Asmani, Tips Menjadi Kepala Sekolah Profesional (Jogjakarta: Diva Press, cet. ke-1, 2012), h. 16.
} 
Salah satu yang dipimipin dan diarahkan oleh kepala sekolah adalah guru. Kepala sekolah harus melakukan berbagai strategi untuk meningkatkan berbagai kompetensi yang dimiliki guru seperti aspek kompetensi pedagogik guru, aspek kompetensi kepribadian guru, aspek kompetensi sosial guru serta aspek kompetensi profesional guru.

\section{Strategi Kepala Sekolah Dalam Meningkatkan Kompetensi Guru Pada Aspek Pedagogik}

Strategi kepala sekolah dalam meningkatkan kompetensi guru pada aspek pedagogik harus dilakukan karena guru merupakan kunci keberhasilan sebuah lembaga pendidikan. Kompetensi pedagogik adalah kemampuan mengelola pembelajaran peserta didik yang meliputi pemahaman terhadap peserta didik, perancangan dan pelaksanaan pembelajaran peserta didik, evaluasi hasil belajar, dan pengembangan peserta didik untuk mengaktualisasikan sebagai potensi yang dimilikinya. ${ }^{40}$ Baik dan buruknya tata cara mengajar guru pada aspek paedagogik akan sangat mempengaruhi citra lembaga pendidikan. Oleh sebab itu sumber daya guru ini harus dikembangkan baik melalui pendidikan dan pelatihan dan kegiatan lain agar kemampuan profesionalnya lebih meningkat.

Kompetensi pedagogik yang harus diperhatikan oleh guru berkaitan dengan berbagai unsur. Salah satu unsurnya meliputi: (1) pemahaman wawasan guru akan landasan dan filsafat pendidikan; (2) guru memahami potensi dan keberagaman peserta didik, sehingga dapat didesain strategi pelayanan belajar sesuai keunikan masing-masing peserta didik; (3) guru mampu mengembangkan kurikulum/silabus baik dalam bentuk dokumen maupun implementasi dalam bentuk pengalaman belajar; (4) guru mampu menyusun rencana dan strategi pembelajaran berdasarkan standar kompetensi dasar; (5) mampu melaksanakan pembelajaran yang mendidik dengan suasana dialogis dan interaktif. Sehingga pembelajaran menjadi aktif, inovatif, kreatif, efektif dan menyenangkan; (6) mampu melakukan evaluasi hasil belajar dengan memenuhi prosedur dan standar yang dipersyaratkan; dan (7) mampu mengembangkan bakat dan minat peserta didik melalui kegiatan intrakurikuler dan ekstrakurikuler untuk mengaktualisasikan berbagai potensi yang dimilikinya. ${ }^{41}$

Dari hasil penggalian data di lapangan diketahui ada beberapa strategi kepala sekolah dalam meningkatkan kompetensi pedagogik guru. Strategi tersebut antara lain memberi kesempatan kepada mereka untuk mengikuti pelatihan, workshop, diklat ataupun seminar yang berkaitan dengan peningkatan kualitas dan kapasitas mereka sebagai guru. Kegiatan tersebut biasanya diadakan oleh KKMI yang jumlah pesertanya terbatas. Satu lembaga sekolah biasanya dihimbau untuk mengirim 1 (satu) atau 2 (dua) orang peserta. Oleh karena itu, kepala sekolah mengadakan bimbingan dengan seluruh dewan guru dan staf yang digunakan sebagai wadah untuk berbagi informasi antar guru. Guru yang

\footnotetext{
${ }^{40}$ Tatang, S, Supervisi Pendidikan (Bandung: Pustaka Setia, 2016), h.203

${ }^{41}$ Sagala, Kemampuan Profesional Guru dan tenaga Kependidikan (Bandung: Alfabeta, 2009), h. 32
} 
menjadi perwakilan untuk mengikuti kegiatan pelatihan, seminar, diklat ataupun lokakarya yang berhubungan dengan pembelajaran maka guru tersebut diwajibkan untuk menyampaikan ilmu yang diperoleh dari kegiatan tersebut. Tujuannya supaya guru yang tidak mengikuti kegiatan juga mendapat ilmu baru walaupun tidak langsung mengikuti pelatihan yang diadakan oleh KKMI. Kemudian ilmu yang telah diperoleh dilaksanakan bersama-sama.

Selain itu kepala sekolah juga melakukan pembinaan serta pengawasan terhadap kinerja guru baik secara langsung maupun tidak langsung. Secara langsung dengan cara kepala sekolah melihat langsung kinerja guru dalam proses pembelajaran. Secara tidak langsung melalui laporan tertulis berupa perangkat pembelajaran yang dibutuhkan dalam kegiatan pembelajaran. Strategi yang dilakukan oleh kepala sekolah dalam meningkatkan kompetensi pedagogik guru membawa perubahan yang positif bagi tenaga pendidik di MI Muhammadiyah 03 Wonoasri Tempurejo Jember. Jadi kegiatan dalam meningkatkan kompetensi pedagogik guru disambut dengan senang hati dan suka rela serta semua guru turut melaksanakan dengan penuh tanggung jawab.

\section{Strategi Kepala Sekolah Dalam Meningkatkan Kompetensi Guru Pada Aspek Kepribadian}

Berdasarkan penelusuran data di lapangan diketahui bahwa strategi kepala sekolah dalam meningkatkan kompetensi kepribadian guru di MI Muhammadiay 03 Wonosari dengan cara memberikan suri tauladan dari bentuk kedisiplinan, tegas, cara berpakaian, dan sikap saling menghormati. Dari strategi ini, guru dapat memiliki kompetensi kepribadian. Kompetensi kepribadian adalah kemampuan kepribadian yang mantap, berakhlak mulia, arif dan wibawa, serta menjadi teladan peserta didik. ${ }^{42}$ Hanya guru-guru yang memiliki kompetensi kepribadian yang utuh dan mantap, yakni kepribadian yang stabil, dewasa, arif, dan berwibawa, menjadi teladan peserta didik dan berakhlak mulia, yang dapat membentuk kepribadian peserta didik yang utuh dan mantap. Sangat mustahil guru yang tidak memiliki kepribadian yang mantap untuk membentuk kepribadian peserta didik yang berkualitas.

Strategi kepala sekolah di MI Muhammadiay 03 Wonosari dalam meningkatkan kompetensi kepribadian guru dengan cara menumbuhkan rasa tanggung jawab. Dalam meningkatkan rasa tanggung jawab guru maka kepala sekolah mempunyai kebijakan bahwa ketika ada guru yang berhalangan untuk mengajar, maka guru tersebut harus mencari guru pengganti. Bisa menghubungi guru piket maupun guru yang sedang ada jam kosong. Namun dengan begitu, guru yang berhalangan hadir harus datang ke sekolah untuk memberikan materi pelajaran atau perangkat pembelajaran yang akan disampaikan oleh guru pengganti. Sehingga kelas tidak terbengkalai dan materi pelajaran dapat disampaikan sesuai jadwal yang telah dibuat. Jadi, strategi kepala sekolah dalam meningkatkan kompetensi guru pada aspek kepribadian guru yaitu

${ }^{42}$ Tatang, S, Supervisi Pendidikan (Bandung: Pustaka Setia, 2016), h.203 
mengadakan pembinaan disiplin guru. Kegiatan ini diharapkan guru bisa menjadi uswatun hasanah atau suri tauladan bagi peserta didik.

\section{Strategi Kepala Sekolah Dalam Meningkatkan Kompetensi Guru Pada Aspek Sosial}

Berdasarkan hasil penelitian diketahui bahwa kepala sekolah di MI Muhammadiay 03 Wonosari berupaya untuk meningkatkan kompetensi guru pada aspek sosial. Kompetensi sosial adalah kemampuan guru untuk berkomunikasi dan berinteraksi secara efektif dan efisien dengan peserta didik, sesama guru, orangtua/wali peserta didik, dan masyarakat sekitar. ${ }^{43}$ Mulyasa menyebutkan sedikitnya terdapat tujuh kompetensi sosial yang harus dimiliki guru agar dapat berkomunikasi dan bergaul secara efektif, baik di sekolah maupun di masyarakat. Ketujuh kompetensi tersebut meliputi: (1) memiliki pengetahuan tentang adat istiadat baik sosial maupun agama; (2) memiliki pengetahuan tentang budaya dan tradisi; (3) memiliki pengetahuan tentang inti demokrasi; (4) memiliki pengetahuan tentang estetika; (5) memiliki apresiasi dan kesadaran sosial; (6) memiliki sikap yang benar terhadap pengetahuan dan pekerjaan; dan (7) setia terhadap harkat dan martabat manusia. ${ }^{44}$

Untuk menciptakan kompetensi social pada guru, maka kepala sekolah melakukan berbagai strategi. Salah satu strateginya adalah menciptakan suasana akrab antara kepala sekolah dengan guru, sesama guru, guru dengan peserta didik, orang tua/wali murid juga dengan masyarakat sekitar. Untuk menciptakan rasa tenang dan nyaman kepala sekolah senantiasa memberikan perhatian kepada guru yang ada di MI Muhammadiyah 03 Wonoasri. Jika terjadi permasalahan internal dalam lembaga maka kepala sekolah segera menangani permasalahan tersebut supaya permasalahan yang ada tidak menjadi besar dan berlarut-larut. Menurut kepala sekolah jika ada masalah internal sesama guru maka hal tersebut akan berpengaruh pada peserta didik dan menjadikan citra lembaga menjadi buruk dalam pandangan masyarakat. Selain itu juga guru harus menjalin komunikasi yang baik dengan wali murid. Kepala sekolah memberi wadah grup komunikasi melalui media telekomunikasi. Karena dengan adanya komunikasi tersebut akan memudahkan guru dalam menyampaikan informasi dan perkembangan peserta didik.

\section{Strategi Kepala Sekolah Dalam Meningkatkan Kompetensi Guru Pada Aspek Profesional}

Berdasarkan hasil penelitian dapat diketahui bahwa kepala sekolah di Ml Muhammadiay 03 Wonosari juga memperhatikan kompetensi professional guru. Kompetensi profesional adalah kemampuan penguasaan materi pelajaran secara luas dan mendalam. ${ }^{45}$ Menurut Mulyasa, Kompetensi profesional secara umum dapat diidentifikasikan dan disarikan tentang ruang lingkup kompetensi profesional guru yang meliputi: (1) mengerti dan dapat menerapkan landasan kependidikan; (2)

\footnotetext{
${ }^{43}$ Tatang, S, Supervisi Pendidikan (Bandung: Pustaka setia, 2016), h.203

${ }^{44}$ Tukiran Taniredja dkk, Guru Yang Profesional (Bandung: Alfabeta, cet. Ke-3, 2018), h. 81

${ }^{45}$ Tatang S, Supervisi Pendidikan (Bandung: Pustaka Setia, 2016), h.203
} 
mengerti dan dapat menerapkan teori belajar sesuai dengan taraf perkembangan peserta didik; (3) mampu menangani dan mengembangkan bidang studi yang menjadi tanggung jawabnya; (4) mengerti dan dapat menerapkan metode pembelajaran yang bervariasi; (5) mampu mengembangkan dan menggunakan berbagai alat, media dan sumber belajar yang relevan; (6) mampu mengorganisasikan dan melaksanakan program pembelajaran; (7) mampu melaksanakan evaluasi hasil belajar peserta didik; (8) mampu menumbuhkan kepribadian peserta didik. ${ }^{46}$

Berdasarkan hasil penelitian dapat diketahui bahwa strategi kepala sekolah di Ml Muhammadiay 03 Wonosari dalam meningkatkan kompetensi guru pada aspek profesional adalah menumbuhkan kreatifitas guru, memotivasi guru, mengembangkan kemampuan guru, serta melakukan supervisi terhadap kinerja guru. Menumbuhkan kreatifitas guru dilakukan kepala sekolah agar guru-guru semangat untuk berinovasi merancang pembelajaran yang mudah dipahami oleh peserta didik. Kepala sekolah setiap tahun mengajak semua dewan guru belajar langsung pada lembaga yang maju melalui kegiatan study banding. Kegiatan ini berfungsi agar para guru bisa melihat secara langsung proses pembelajaran, metode yang digunakan, dan belajar untuk meningkatkan kompetensinya sebagai guru. Kemudian mempraktekkan ilmu yang diperoleh dalam kegiatan tersebut di lembaga.

Dalam meningkatkan kompetensi profesional guru kepala sekolah juga memberikan kesempatan pada guru untuk mengikuti pelatihan dan lokakarya maupun diklat. Kegiatan tersebut diharapkan mampu mengembangkan kemampuan guru serta menambah wawasan guru tentang dunia pendidikan dan mampu menerapkan ilmu yang diperoleh dalam proses pembelajaran demi terciptanya mutu pendidikan yang baik. Kepala sekolah juga melaksanakan supervisi pada kinerja guru. Hal ini bertujuan supaya kepala sekolah dapat mengetahui sebatas mana kemampuan guru dalam menyampaikan materi, membuat perangkat pembelajaran serta melaksanakan tugas dan fungsinya sebagai guru.

\section{E. KESIMPULAN}

Dari beberapa uraian yang telah dijelaskan, maka hasil penelitian ini dapat disimpulkan sebagai berikut: 1) strategi kepala sekolah dalam meningkatkan kompetensi guru pada aspek pedagogik dengan cara mengadakan pembinaan dan pengawasan kepada guru terkait dengan proses pembelajaran di kelas; 2) strategi kepala sekolah dalam meningkatkan kompetensi guru pada aspek kepribadian dengan cara memberikan motivasi dan contoh yang baik pada guru untuk selalu berbuat yang terbaik untuk peserta didik dan kemajuan lembaga; 3) strategi kepala sekolah dalam meningkatkan kompetensi guru pada aspek sosial dengan cara menciptakan nuansa kebersamaan dan keharmonisan dengan meningkatkan komunikasi antar dewan guru sehingga tercipta suasana yang guyub rukun dalam lingkungan sekolah; dan 4) strategi

\footnotetext{
${ }^{46}$ Tukiran Taniredja dkk, Guru Yang Profesional (Bandung: Alfabeta, cet. Ke-3, 2018), h. 74
} 
kepala sekolah dalam meningkatkan kompetensi guru pada aspek profesional dengan cara mengadakan pembinaan disiplin guru, mengikut sertakan guru dalam kegiatan pelatihan, lokakarya, diklat, seminar, KKG, MGMP untuk memperluas pengetahuan guru dalam rangka meningkatkan kualitas pembelajaran dan prestasi peserta didik. Mengadakan supervisi kinerja guru untuk mengevaluasi kinerja guru dan meningkatkan kompetensinya.

\section{F. DAFTAR PUSTAKA}

Arikunto, Suharsimi. 2002. Prosedur Penelitian Suatu Pendekatan Praktek. Jakarta: Rineka Cipta.

Asmani, Jamal Ma'mur. 2012. Tips Menjadi Kepala Sekolah Profesional. Jogjakarta: Diva Press.

Bakar, Yunus Abu dkk. 2009. Profesi Keguruan. Surabaya: AprintA.

Kompri. 2017. Standarisasi Kompetensi kepala Sekolah Pendekatan Teori Untuk Praktek Profesional. Jakarta: Kencana, 2017.

Moleong, Lexy J. 2016. Metodologi Penelitian Kualitatif. Bandung: PT Remaja Rosda Karya.

Mufidah, Luk-luk Nur. 2008. Supervisi Pendidikan. Jember: Center for Society Studies.

Mulyasa,E. 2018. Menjadi Kepala Sekolah Profesional. Bandung: PT Remaja Rosdakarya.

Notoatmodjo, Soekidjo. 1998. Pengembangan Sumber Daya Manusia. Jakarta: Rineka Cipta.

Nurul Anam dan Moh. Rofid Fikroni, 2020. Rabbani Education: Basic Concepts, Design and Implications of Rabbani Education Learning. Jurnal Tribakti: Jurnal Pemikiran Keislaman, Vol. 31 No. 1 Januari. DOI: https://doi.org/10.33367/tribakti.v31i1.975.

S, Tatang. 2016. Supervisi Pendidikan. Bandung: CV Pustaka Setia.

Sahertian, Piet, A. 2008. Profil Pendidikan Profesional. Yogyakarta: Andi Offset.

Samana. 2006. Profesionalisme Keguruan. Yogyakarta: Kanisius.

Satori, Djaman. 2009. Metodologi Penelitian Kualitatif. Bandung: Alfabeta. Sondang, Siagian P. 2004. Manajemen strategi. Jakarta: Bumi aksara.

Sugiono. 2006. Metode Penelitian Kualitatif, Kualitatif dan R\&D. Bandung: PT Remaja Rosda Karya.

Sulistiyorini. 2009. Manajemen Pendidikan Islam. Surabaya: Elkaf.

Swasto, Bambang. 1996. Manajemen Sumber Daya Manusia. Malang: Fakultas IImu Administrasi Universitas Brawijaya.

Taniredja, Tukiran dkk. 2018. Guru Yang Profesional. Bandung: Alfabeta. 